\title{
Thermal Manipulation Mid-term Broiler Chicken Embryogenesis: Effect on Muscle Growth Factors and Muscle Marker Genes.
}

\section{-Author(s)}

\section{Al-Zghoul MB' \\ Al-Natour MQ" \\ Dalab AS"II \\ Alturki OI"II \\ Althnaian T"II \\ Al-ramadan SYIII \\ Hannon KMiv \\ El-Bahr SMv}

Department of Basic Medical Veterinary Sciences, Faculty of Veterinary Medicine, Jordan University of Science and Technology.

" Department of Veterinary Pathology and Public Health, Faculty of Veterinary Medicine, Jordan University of Science and Technology.

III Department of Anatomy, College of Veterinary Medicine, King Faisal University, Saudi Arabia.

Iv Department of Basic Medical Sciences, Purdue University, West Lafayette, IN, United States.

Department of Biochemistry, Faculty of Veterinary Medicine, Alexandria University, Egypt Department of Physiology, Biochemistry and Pharmacology, College of Veterinary Medicine, King Faisal University, Saudi Arabia.

\section{-Mail Address}

Corresponding author e-mail address

Dr. Mohammad Borhan Al-Zghoul, DVM, $\mathrm{PhD}$

Department of Basic Medical Veterinary Sciences, Faculty of Veterinary Medicine, Jordan University of Science and

Technology, P.O. Box 3030, Irbid 22110, Jordan.

Tel: $\quad$ +(962) 79034-0114

Email: alzghoul@just.edu.jo

\section{EKeywords}

Embryogenesis, IGF-1, MyoD, myostatin, thermal manipulation.

\section{ABSTRACT}

Thermal manipulation (TM) during broiler chicken embryogenesis has been shown to promote muscle development and growth. However, the molecular bases of promoting broiler muscle development and growth are not fully understood. The aim of this study was to investigate the molecular bases of muscle growth and development in broiler chickens subjected to TM. This included the investigating of the changes in mRNA expression levels of muscle marker genes, namely MyoD, myogenin, paired box transcription factor (Pax7) and proliferating cell nuclear antigen (PCNA), and muscle growth factors namely insulin-like growth factor 1 (IGF-1), myostatin and growth hormone $(\mathrm{GH})$ during embryogenesis and on posthatch days 10 and 28 . Fertile Cobb eggs $(n=1500)$ were divided into four groups. Eggs in the first group (control) were incubated at $37.8^{\circ} \mathrm{C}$ and $56 \% \mathrm{RH}$, whereas, eggs in the second group $\left(\mathrm{TM}_{1}\right)$ third group $\left(\mathrm{TM}_{2}\right)$ and fourth group $\left(\mathrm{TM}_{3}\right)$ were subjected to $39{ }^{\circ} \mathrm{C}$ and $65 \% \mathrm{RH}$ daily during embryonic days (ED) 12-18 for 9, 12, and 18 hours, respectively. Body weight (BW) during embryogenesis and posthatch days $(1,3,5,7,14,21,28$ and 35) was recorded. mRNA expression levels of muscle marker genes and muscle growth factor genes during ED 12, 14, 16 and 18 and on posthatch days 10 and 28 were analyzed using real-time RT-PCR. TM upregulated the mRNA expressions of muscle marker and growth factors genes. This upregulation was accompanied by improvement of body weight near and at market age.

\section{INTRODUCTION}

Agricultural scientists and farmers have long been concerned with the improvement to the muscle mass of meat-producing livestock (Bass et al., 1999). The productivity of these animals is directly related to the cellular and molecular mechanisms regulating skeletal muscle myoblasts growth and development of muscle mass (Koohmaraie et al., 2002).

Embryonic muscle-precursor cells, originating from multipotential mesodermal cells, undergo myogenic determination and give rise to myoblasts (Ordahl et al., 2000). In muscle cells, as in a variety of cell types, a balance of opposing cellular signals controls proliferation and differentiation. At birth, a high number of proliferating satellite cells are found in skeletal muscle nuclei; however, at the end of the growth phase, their numbers are reduced to less than $5 \%$ of total muscle fiber nuclei and most have become quiescent (Hawke and Garry, 2001). The muscle-specific basic helix-loop-helix (bHLH), a family of transcription factors, regulates the proliferation and differentiation of myoblasts (Weintraub, 1993). Upon satellite cell activation, these transcription factors are expressed in a sequential pattern. Initially, Myf5 and MyoD are expressed in the proliferating progeny, and then myogenin is 
Al-Zghoul MB, Al-Natour MQ, Dalab AS, Alturki OI, Althnaian T, Al-ramadan SY, Hannon KM
Thermal Manipulation Mid-term Broiler Chicken Embryogenesis: Effect on Muscle Growth Factors and Muscle Marker Genes. expressed as the cells enter differentiation (Cornelison and Wold, 1997).

Previously, it has been shown that incubation conditions may affect chicken embryo development (Lourens et al., 2005; Lourens et al., 2007). Temperature is considered as the most important environmental factor during chicken embryo incubation (Decuypere and Michels, 1992). Incubation temperature has a significant effect on hatchability rate, chick quality, and posthatch growth performance parameters (Decuypere \& Michels, 1992; Lourens et al., 2005). Thermal manipulation, in which the embryos are exposed to high or low temperatures during susceptible periods of broiler embryogenesis, has been reported to enhance muscle growth and to improve the acquisition of thermotolerance of broiler chickens (Yalcin \& Siegel 2003; Yahav et al., 2004; Piestun et al., 2008a; Piestun et al., 2008b; Al-Zhgoul et al., 2013; Al-Zghoul et al., 2015; Piestun et al., 2015). However, the molecular bases for promoting muscle development and growth are not fully understood (Decuypere \& Michels, 1992; Piestun et al., 2009; Al-Zhgoul et al., 2013). The aim of this study was to investigate the molecular bases of muscle growth and development of broiler chickens subjected to thermal manipulation $\left(39^{\circ} \mathrm{C}\right.$ and $65 \%$ for 9,12 or 18 h) daily on embryonic days (ED)1218. Changes in mRNA expression levels of muscle marker genes, namely MyoD, myogenin, paired box transcription factor (Pax7) and proliferating cell nuclear antigen (PCNA), and muscle growth factors, namely insulin-like growth factor 1 (IGF-1), myostatin, and growth hormone $(\mathrm{GH})$ were investigated during embryogenesis and on posthatch days 10 and 28 . Results of this study provide an insight into the molecular bases of muscle development and growth of thermally-manipulated broilers.

\section{MATERIALS AND METHODS}

\section{Egg incubation and hatching management}

All experimental procedures and management conditions used in this study were approved by the King Faisal University Animal Care and Use Committee (KFU-ACUC).

Fertile Cobb eggs $(n=1700)$ were obtained from one breeder flock (Riyadh, Saudi Arabia) and incubated in semi-commercial incubators (type OVAEasy380AdvanceSeries II, Brinsea, Sandford, UK). Small $(<55 \mathrm{~g})$ and large $(>75 \mathrm{~g})$ eggs were rejected. One thousand and five hundred $(1,500)$ normal weight eggs were selected, with an average weight of $62 \pm 2 \mathrm{~g}$. The selected eggs were divided into four incubation treatment groups (375 each). Eggs in the control group were maintained at $37^{\circ} \mathrm{C}$ and $56 \%$ relative humidity $(\mathrm{RH})$ throughout the incubation period; eggs in the $\mathrm{TM}_{1}$ group were subjected to $\mathrm{TM}$ of $39^{\circ} \mathrm{C}$ for $9 \mathrm{~h}$ and $65 \% \mathrm{RH}$ daily on ED 12-18; eggs in the $\mathrm{TM}_{2}$ group were subjected to $\mathrm{TM}$ of $39^{\circ} \mathrm{C}$ for $12 \mathrm{~h}$ and $65 \% \mathrm{RH}$ daily on ED 12-18; and eggs in the $\mathrm{TM}_{3}$ group were subjected to $\mathrm{TM}$ of $39^{\circ} \mathrm{C}$ for $18 \mathrm{~h}$ and $65 \%$ RH daily on ED 12-18. After the TM application periods, eggs were maintained at $37.8^{\circ} \mathrm{C}$ and $56 \%$ relative humidity $(\mathrm{RH})$.

At hatch, the number of hatched chicks was recorded. After feather drying, the one-day-old chicks were transferred to King Faisal University Agricultural Research Station, Department of Anatomy, where the field experiment was conducted. As recommended in the Cobb Broiler Management Guide (Cobb-Vantress 2013), chicks were distributed in floor pens (10 birds/ $\mathrm{m}^{2}$ ) at $33^{\circ} \mathrm{C}$, and the temperature was gradually decreased to $24^{\circ} \mathrm{C}$ on posthatch day 21 . From posthatch day 24 until day 35, the temperature was maintained at $21^{\circ} \mathrm{C}$. Birds were fed a commercial feed for five weeks. Feed and water were provided ad libitum. Birds were individually weighed daily during the first week posthatch and at days 10,14, 21, 28 and 35 of age, using $0.01-\mathrm{g}$ precision scale to determine body weight (BW).

\section{Sample collection}

Pectoral muscle mRNA expression levels of muscle marker genes (MyoD, myogenin, Pax7 and PCNA) and muscle growth factors (IGF-1, GH and myostatin) were evaluated using semi-quantitative real-time polymerase chain reaction (RT-PCR) analyses using a real-time thermal cycler (CFX96 Touch TM Real time PCR, BIO-RAD, California, USA). One hundred milligram of Pectoral muscle samples were collected from 80 embryos (five embryos per treatment group per day) on ED 12, 14, 16 and 18, and from 40 chicks (five chicks per treatment group per day) on posthatch days 10 and 28 .

\section{RNA isolation and semi-quantitative RT- PCR analyses}

Total RNA was extracted from homogenated muscle tissue samples using the TRIzol/chloroform/isopropanol method, followed by the removal of supernatants. The RNA pellet was then dissolved in diethylpyrocarbonate (DEPC)-treated RNase-free water (Ambion, Austin, 
Al-Zghoul MB, Al-Natour MQ, Dalab AS, Alturki OI, Althnaian T, Al-ramadan SY, Hannon KM
Thermal Manipulation Mid-term Broiler Chicken Embryogenesis: Effect on Muscle Growth Factors and Muscle Marker Genes.
TX). DNA was removed using DNase I kit (Ambion, Austin, TX), and the RNA samples were checked for concentration and purity (260:280 nm absorbency). Two $\mu \mathrm{g}$ of RNA were reverse transcribed to CDNA in a reaction mixture using iScript CDNA Synthesis Kit (BIORAD, California, USA). The CDNA was then used for semi-quantitative RT-PCR (CFX96 Touch TM Real time $P C R, B I O-R A D$, California, USA). The semi-quantitative RT-PCR was performed using the ssoAdvanced TM SYBR Green Supermix kit (BIO-RAD, California, USA). Briefly, the $20 \mu \mathrm{L}$ reaction mix was prepared from 10 $\mu \mathrm{L}$ of master mix; $2 \mu \mathrm{L}$ forward primer (10 pmol); $2 \mu \mathrm{L}$ reverse primer (10 pmol); $2 \mu \mathrm{L}$ cDNA of the sample and $4 \mu \mathrm{L}$ of nuclease-free water. Cycling parameters were $50^{\circ} \mathrm{C}$ for $2 \mathrm{~min}, 95^{\circ} \mathrm{C}$ for $15 \mathrm{~min}, 40$ cycles of $95^{\circ} \mathrm{C}$ for $10 \mathrm{~s}$, followed by $30 \mathrm{~s}$ at $55^{\circ} \mathrm{C}$ and $72^{\circ} \mathrm{C}$ for $10 \mathrm{~s}$ with final melting at $95^{\circ} \mathrm{C}$ for $20 \mathrm{~s}$. Duplicates from each cDNA were analyzed, fluorescence emission was detected, and relative quantification was calculated automatically using CFX manager ${ }^{\mathrm{TM}}$ software V3.1 (BioRad, Hercules, CA, USA).

\section{Primers design}

Sequences of broiler chicken MyoD, myogenin, Pax7, PCNA, IGF-1, GH, myostatin, and GAPDH were obtained from the gene bank (accession number: (NM_001004384.2, NM_204359.2, AF019621.1, NM_204214.1， FJ882411.1， NM_205065.1, NM_204170.2 and NM_204305.1)). Using these sequences, primers were designed for each gene for the semi-quantitative RT-PCR analyses. All primers were designed using IDT Primerquest software (http://eu.idtdna.com/PrimerQuest /Home/Index). The sequences of the primers are listed in (Table 1).

Table 1 - Oligonucleotides used for expression analysis of chicken genes and the annealing temperatures (AT).

\begin{tabular}{|c|c|c|c|}
\hline Gene & Prim & er sequences & AT \\
\hline cMyoD & $\begin{array}{l}(\mathrm{F}) \\
(\mathrm{R})\end{array}$ & $\begin{array}{l}\text { 5'TACCCAGTGCTGGAGCACTA3’ } \\
\text { 5'GTCTTGGAGCTTGGCTG AACT3' }\end{array}$ & $57^{\circ} \mathrm{C}$ \\
\hline cMyogenin & $\begin{array}{l}(\mathrm{F}) \\
(\mathrm{R})\end{array}$ & $\begin{array}{l}\text { 5`AGCAGCCTCAACCAGCAGGA3` } \\
\text { 5'TCTGCCTGGTCATCGCTCAG3` }\end{array}$ & $58^{\circ} \mathrm{C}$ \\
\hline CPax 7 & $\begin{array}{l}(\mathrm{F}) \\
(\mathrm{R})\end{array}$ & $\begin{array}{l}5^{`} \text { ACTGTGCCCTCAGTGAGTTCGATT3' } \\
5^{\prime} \text { ATTCGACATCGGAGCCTTCATCCA3’ }\end{array}$ & $66.8^{\circ} \mathrm{C}$ \\
\hline CPCNA & $\begin{array}{l}\text { (F) } \\
(\mathrm{R})\end{array}$ & $\begin{array}{l}\text { 5`ACGCATTTGTAGAGACCTCAGCCA3` } \\
\text { 5`AGTCAGCTGGACTGGCTCATTCAT3` }\end{array}$ & $64.9^{\circ} \mathrm{C}$ \\
\hline cMyostatin & $\begin{array}{l}\text { (F) } \\
(\mathrm{R}) \\
\end{array}$ & $\begin{array}{l}\text { 5`ATGCAAAAGCTAGCAG TC3’ } \\
\text { 5'TCATGAGCACCCGCAACGAT3' }\end{array}$ & $52^{\circ} \mathrm{C}$ \\
\hline CIGF-I & $\begin{array}{l}(F) \\
(R)\end{array}$ & $\begin{array}{l}5^{\prime} \text { CGTACAGAGCGTGCAGATT3’ } \\
5^{\prime} \text { CGTAC AGAGCGTGCAGATT3' }\end{array}$ & $55^{\circ} \mathrm{C}$ \\
\hline $\mathrm{cGH}$ & $\begin{array}{l}(F) \\
(R)\end{array}$ & $\begin{array}{l}5^{\prime} \text { GACCAGAGGTACACCAACAAA3' } \\
5^{\prime} \text { GACTGGATGAGAACCAGTGAAA3' }\end{array}$ & $57^{\circ} \mathrm{C}$ \\
\hline cGAPDH & $\begin{array}{l}\text { (F) } \\
(\mathrm{R})\end{array}$ & 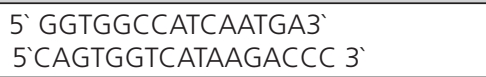 & $52^{\circ} \mathrm{C}$ \\
\hline
\end{tabular}

AT: Annealing Temperature

\section{Statistical analysis}

Body weight, relative expression of mRNA levels of MyoD, myogenin, Pax7, PCNA, IGF-1, GH, and myostatin were expressed as means \pm standard error (SE). One-way analysis of variance, followed by allpairs Bonferroni test, was used to compare different parameters among treatment groups (control vs. TM groups) using IBM SPSS Statistics 23 Software (IBM software, Chicago, USA). Differences were considered significant at $p<0.05$.

\section{RESULTS}

\section{Effect of thermal manipulation on embryonic and posthatch body weight}

The effect of TM on embryo BW is shown in Figure 1. On ED 12, $T M_{2}$ and $T M_{3}$ embryos were significantly heavier than the control and TM $\mathrm{T}_{1}$ embryos $(p<0.05)$. However, on ED 14 and ED16, there were no significant differences in BW among the treatment groups ( $p>0.05)$. On ED 18, TM significantly increased embryonic BW when compared with the control $(p<0.05)$.

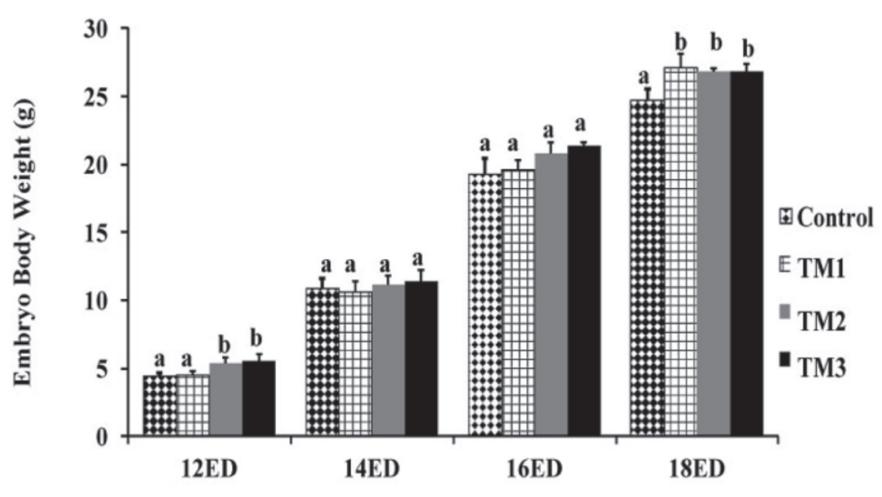

Embryonic Days

Figure $\mathbf{1}$ - The effect of thermal manipulation (TM) on the body weight of broiler embryos subjected to different thermal manipulation treatments during embryogenesis) $\mathrm{n}=5$ ). Control $=37.8^{\circ} \mathrm{C} ; \mathrm{TM} 1=$ Thermal manipulation at $39^{\circ} \mathrm{C}$ for $9 \mathrm{~h}$; TM2 $=$ Thermal manipulation at $39^{\circ} \mathrm{C}$ for $12 \mathrm{~h}$; TM3 $=$ Thermal manipulation at $39^{\circ} \mathrm{Cfor} 18 \mathrm{~h}$. a, b Within the same ED, means \pm SD with different superscripts differ significantly $(p<0.05)$.

Body weight of control and TM chicks during the posthatch period (first week of age, and 14, 21, 28, and 35 of age) are shown in Figure 2. During the first three weeks of age, except for day 1 (TM : 53.9, TM: 53.7, $\mathrm{TM}_{3}: 54.7$ vs. control:49.1) and day 3 ( $\mathrm{TM}_{1}:$ 62.3, $\mathrm{TM}_{2}: 62.3, \mathrm{TM}_{3}: 62.8$ vs. control:58.9), no significant changes in BW were observed among the treatment groups ( $p>0.05)$. However, on posthatch day 28, the BW of all TM groups were significantly higher compared with the control group $(p<0.05)$. However, on posthatch day 35 , the $\mathrm{BW}$ of $\mathrm{TM}_{2}$ and $\mathrm{TM}_{3}$ groups were significantly higher compared with those of the control and TM 1 groups $(\mathrm{p}<0.05)$. 
Al-Zghoul MB, Al-Natour MQ, Dalab AS, Alturki OI, Althnaian T, Al-ramadan SY, Hannon KM

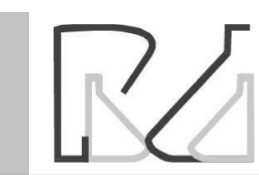

Thermal Manipulation Mid-term Broiler Chicken Embryogenesis: Effect on Muscle Growth Factors and Muscle Marker Genes.

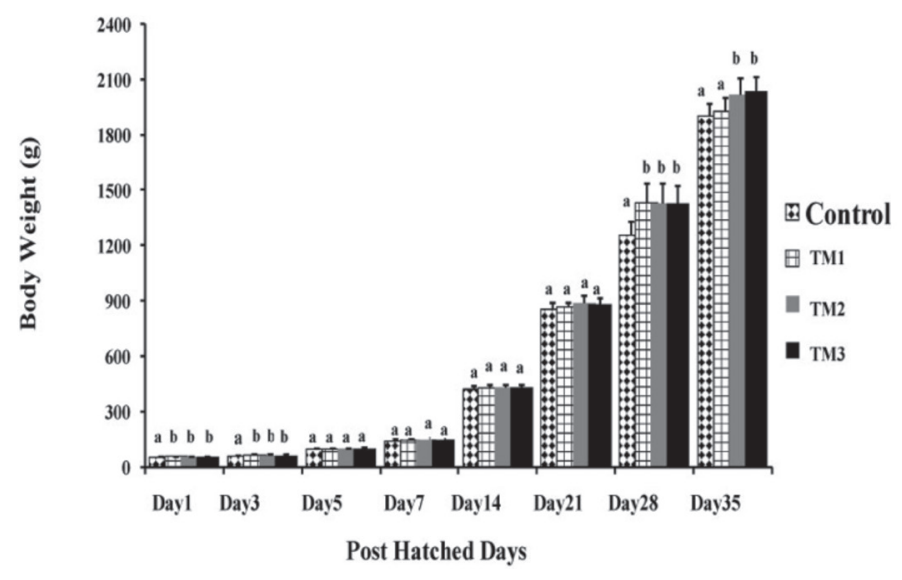

Figure $\mathbf{2}$ - The effect of thermal manipulation (TM) during embryogenesis on posthatch body weight of broilers from day 1 to day $35(n=20)$. Control $=37.8^{\circ} \mathrm{C} ; \mathrm{TM} 1=$ Thermal manipulation at $39^{\circ} \mathrm{C}$ for $9 \mathrm{~h}$; $\mathrm{TM} 2=$ Thermal manipulation at $39^{\circ} \mathrm{C}$ for $12 \mathrm{~h}$; $\mathrm{TM} 3=$ Thermal manipulation at $39^{\circ} \mathrm{C}$ for $18 \mathrm{~h}$. a-c Within the same day, means \pm SD with different superscripts differ significantly $(p<0.05)$.

\section{Effects of thermal manipulation on mRNA expression levels of muscle marker genes (MyoD, myogenin, Pax7 and PCNA)}

The effects of embryoinic thermal manipulation on MyoD mRNA expression on ED 12, 14, 16, and 18, and on posthatch days 10 and 28 are shown in Figure 3 A-B. MyoD mRNA expression was significantly higher in groups $\mathrm{TM}_{2}$ and $\mathrm{TM}_{3}$ on ED 12 and in all TM groups on ED 14 (Figure 3A) $(p<0.05)$. However, on ED 16, MyoD mRNA expression in the $\mathrm{TM}_{3}$ group was significantly higher than the control, $\mathrm{TM}_{1}$, and $\mathrm{TM}_{2}$ groups, which remained comparable (Figure $3 A)(p<0.05)$. Similarly, on ED 18, there were no significant differences in MyoD
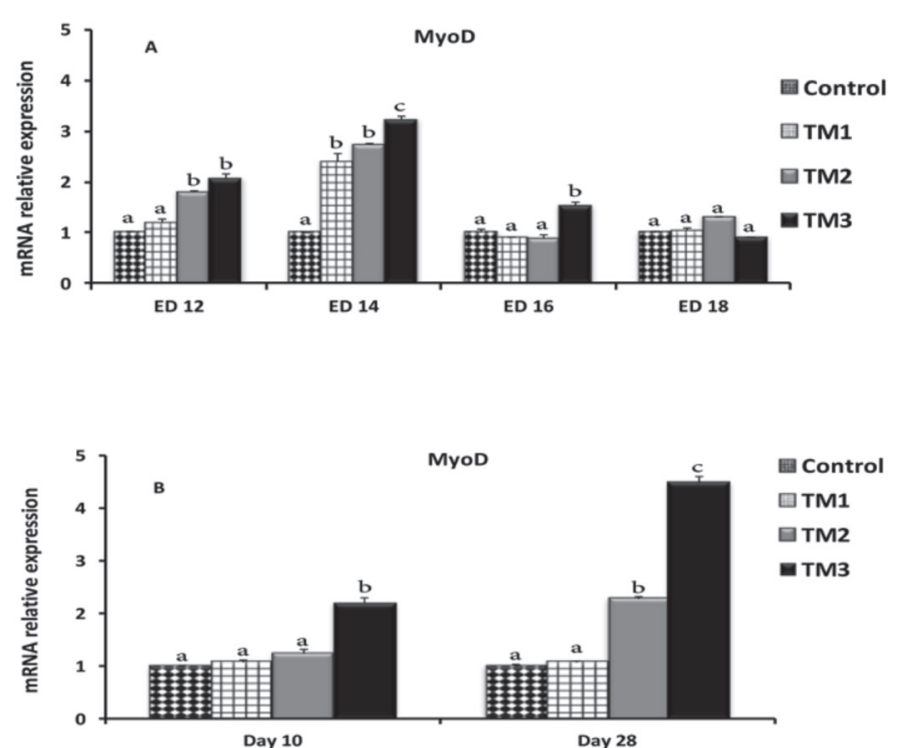

Figure 3 - The effect of thermal manipulation (TM) during embryogenesis on MyoD gene expression during embryonic days 12-18 (A) and posthatching days 10 and 28 (B) $(\mathrm{n}=20)$. Control $=37.8^{\circ} \mathrm{C} ; \mathrm{TM} 1=$ Thermal manipulation at $39^{\circ} \mathrm{C}$ for $9 \mathrm{~h} ; \mathrm{TM} 2=$ Thermal manipulation at $39^{\circ} \mathrm{C}$ for $12 \mathrm{~h} ; \mathrm{TM} 3=$ Thermal manipulation at $39^{\circ} \mathrm{C}$ for $18 \mathrm{~h}$. a-c Within the same day, means \pm SD with different superscripts differ significantly $(p<0.05)$.
mRNA expression among the treatment groups (Figure 3A) ( $p>0.05)$. On day 10 posthatch, TM significantly increased MyoD mRNA expression in the $\mathrm{TM}_{3}$ group compared with the control, $\mathrm{TM}_{1}$ and $\mathrm{TM}_{2}$ groups, which remained comparable (Figure 3B) $(p<0.05)$. However, on day 28 posthatch, higher expression of MyoD was only observed in $\mathrm{TM}_{2}$ and $\mathrm{TM}_{3}$ groups compared with the control and $\mathrm{TM}_{1}$ groups, which remained comparable (Figure $3 B)(p<0.01)$.

The effects of embryo thermal manipulation on myogenin mRNA expression on ED 12, 14, 16, and 18 , and on posthatch days 10 and 28 are shown in Figure 4 A-B. On ED 12, mRNA expression of myogenin was significantly lower in the $\mathrm{TM}_{1}$ and $\mathrm{TM}_{2}$ groups and significantly higher in the $\mathrm{TM}_{3}$ group relative to the control group (Figure $4 A)(p<0.05)$. On ED 14, all TM groups presented significantly higher myogenin mRNA expression compared with the control group $(p<0.05)$, and myogenin mRNA expression was higher noted in the $\mathrm{TM}_{1}$ and $\mathrm{TM}_{3}$ groups compared with $\mathrm{TM}_{2}$ (Figure 4A) $(p<0.05)$. On ED 16 and 18, TM promoted significantly higher myogenin mRNA expression in the $\mathrm{TM}_{2}$ and $\mathrm{TM}_{3}$ groups compared with the control and $\mathrm{TM}_{1}$ groups, which remained comparable (Figure 4A) $(p<0.05)$. At day 10 of age, TM resulted in significantly higher in myogenin mRNA expression compared to the control with time-dependent manner (Figure 4B) $(p<0.05)$. However, on day 28, the TM3 group presented significantly higher myogenin mRNA expression compared with the control, $\mathrm{TM}_{1}$ and $\mathrm{TM}_{2}$ groups, which remained comparable (Figure $4 B)(p<0.05)$.
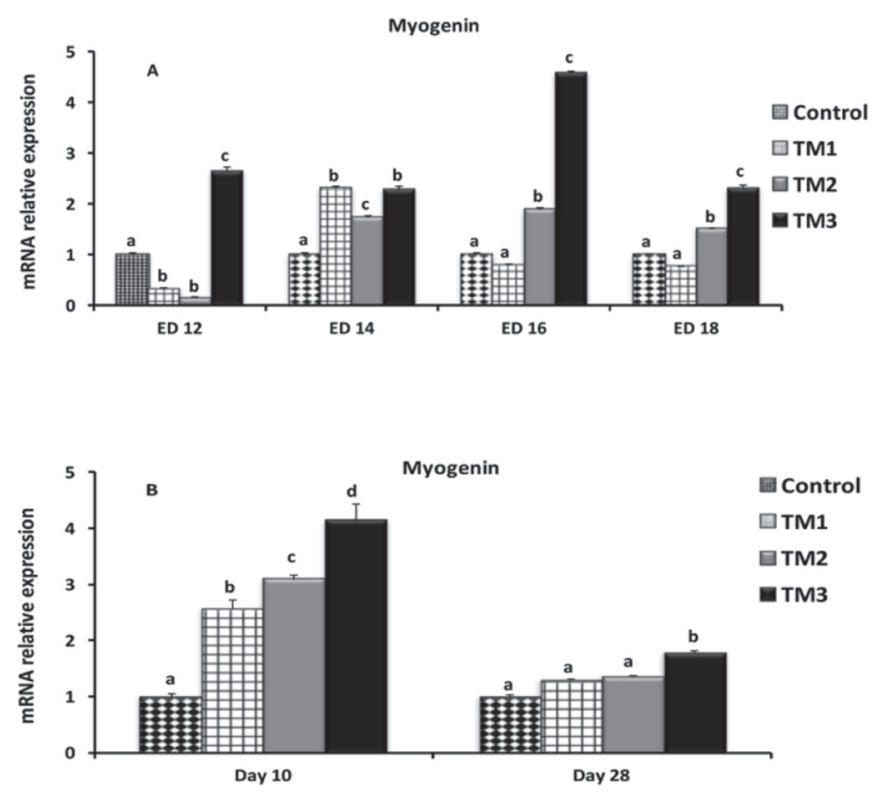

Figure 4 - The effect of thermal manipulation (TM) during embryogenesis on myogenin gene expression during embryonic days 12-18 (A) and posthatch days 10 and 28 (B) (n = 20). Control $=37.8^{\circ} \mathrm{C} ; \mathrm{TM} 1=$ Thermal manipulation at $39^{\circ} \mathrm{C}$ for $9 \mathrm{~h} ; \mathrm{TM} 2=$ Thermal manipulation at $39^{\circ} \mathrm{C}$ for $12 \mathrm{~h}$; $\mathrm{TM} 3=$ Thermal manipulation at $39^{\circ} \mathrm{C}$ for $18 \mathrm{~h}$. a-d Within the same day, means \pm SD with different superscripts differ significantly $(p<0.05)$. 
Al-Zghoul MB, Al-Natour MQ, Dalab AS, Alturki OI, Althnaian T, Al-ramadan SY, Hannon KM
Thermal Manipulation Mid-term Broiler Chicken Embryogenesis: Effect on Muscle Growth Factors and Muscle Marker Genes.
The effects of embryo thermal manipulation on PCNA mRNA expression on embryonic days 12, 14, 16 , and 18, and on posthatch days 10 and 28 are shown in Figure $5 \mathrm{~A}-\mathrm{B}$. On ED 12, there were no significant differences in PCNA mRNA expression among treatment groups (Figure 5A) $\quad(p>0.05)$. However, on ED 14 and 16, PCNA mRNA expression was significantly higher in the $\mathrm{TM}_{3}$ group compared with the other treatment groups (Figure 5A) $(p<0.05)$. On ED 18, PCNA mRNA expression in the $\mathrm{TM}_{2}$ and $\mathrm{TM}_{3}$ groups were significantly higher than the control and $\mathrm{TM}_{1}$ groups, which remained comparable (Figure 5A) $(p<0.05)$. On posthatch days 10 and 28 , TM groups presented significantly higher PCNA mRNA expression compared with the controls $(p<0.05)$, with the highest expression observed in $\mathrm{TM}_{2}$ and $\mathrm{TM}_{3}$ groups in a timedependent manner (Figure 5B) $(p<0.05)$.
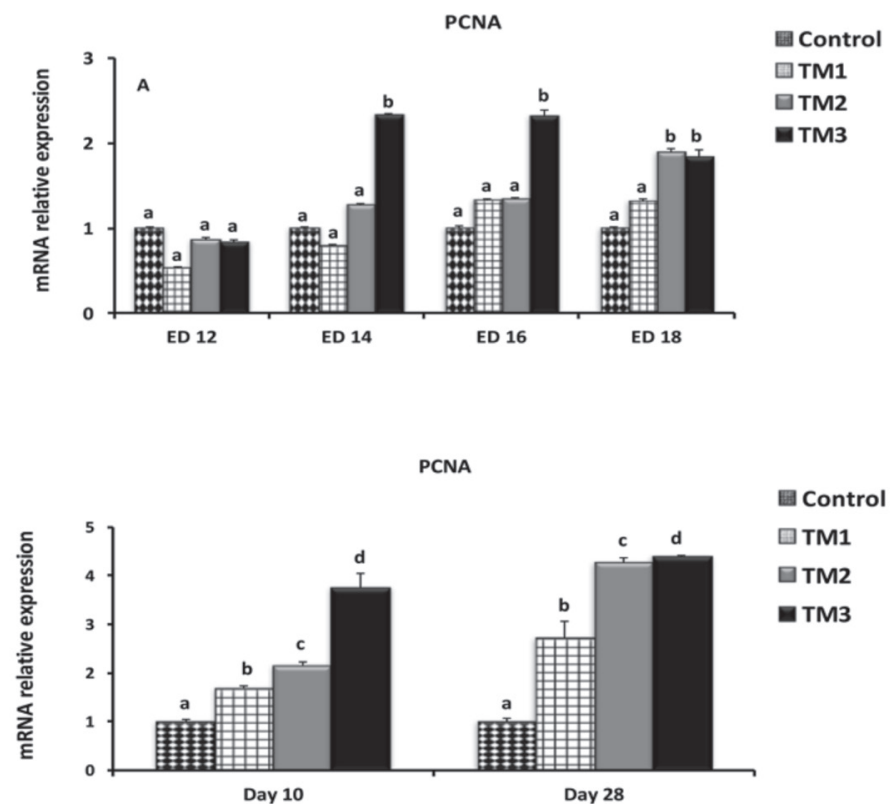

Figure 5 - The effect of thermal manipulation (TM) during embryogenesis on PCNA gene expression during embryonic days 12-18 (A) and posthatch days 10 and 28 (B) (n $=20$ ). Control $=37.8^{\circ} \mathrm{C} ; \mathrm{TM} 1=$ Thermal manipulation at $39^{\circ} \mathrm{C}$ for $9 \mathrm{~h} ; \mathrm{TM} 2=$ Thermal manipulation at $39^{\circ} \mathrm{C}$ for $12 \mathrm{~h} ; \mathrm{TM} 3=$ Thermal manipulation at $39^{\circ} \mathrm{C}$ for $18 \mathrm{~h}$. a-d Within the same day, means $\pm S D$ with different superscripts differ significantly $(p<0.05)$.

The effects of embryo thermal manipulation on Pax7 mRNA expression on ED 12, 14, 16, and 18, and on posthatch days 10 and 28 are shown in Figure 6 A-B. On ED 12 and 14, Pax7 mRNA expression of all TM groups was significantly higher relative to the control (Figure 6A) $(p<0.05)$. However, on ED 16, higher Pax7 expression was observed only in the $\mathrm{TM}_{3}$ group ( $p<0.05)$, while on ED 18, Pax7 expression was higher in the $\mathrm{TM}_{2}$ and $\mathrm{TM}_{3}$ groups compared with the $\mathrm{TM}_{1}$ and control groups, which remained comparable (Figure 6A) $(p<0.05)$. On day 10 posthatch, except for $\mathrm{TM}_{1}, \mathrm{TM}$ groups presented significantly higher Pax7
mRNA expression compared with the control, with the highest expression observed in the $\mathrm{TM}_{3}$ group (Figure $6 B)(p<0.05)$. On day 28 posthatch, TM significantly increased in Pax7 mRNA expression compared with the control, with the highest expression observed in the $\mathrm{TM}_{2}$ and $\mathrm{TM}_{3}$ groups (Figure $\left.6 \mathrm{~B}\right)(\mathrm{p}<0.05)$.
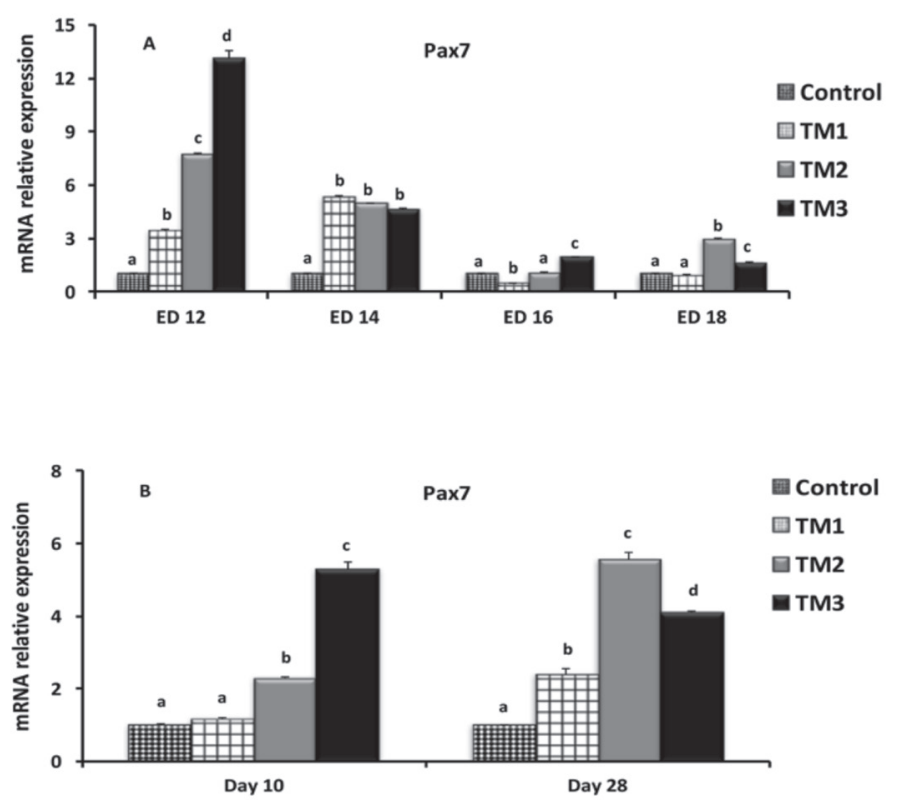

Figure 6 - The effect of thermal manipulation (TM) during embryogenesis on Pax7 gene expression during embryonic days 12-18 (A) and posthatch days 10 and 28 (B) $(\mathrm{n}=20)$. Control $=37.8^{\circ} \mathrm{C} ; \mathrm{TM} 1=$ Thermal manipulation at $39^{\circ} \mathrm{C}$ for $9 \mathrm{~h} ; \mathrm{TM} 2=$ Thermal manipulation at $39^{\circ} \mathrm{C}$ for $12 \mathrm{~h} ; \mathrm{TM} 3=$ Thermal manipulation at $39^{\circ} \mathrm{C}$ for $18 \mathrm{~h}$ a-d Within the same day, means \pm SD with different superscripts differ significantly $(p<0.05)$.

\section{Effects of thermal manipulation on mRNA expression levels of muscle growth factors (IGF-1, GH and myostatin).}

The effects of embryo thermal manipulation on IGF1 mRNA expression onembryonic days 12, 14, 16, and 18 , and on posthatch days 10 and 28 are shown in Figure 7 A-B. From ED 12 to ED 16, TM significantly increased IGF-1 mRNA expression compared with the control (Figure 7A) $(p<0.05)$. On ED 18, IGF-1 mRNA expression of $\mathrm{TM}_{2}$ and $\mathrm{TM}_{3}$ groups was significantly higher compared with the control and $\mathrm{TM}_{1}$ groups, which remained comparable (Figure 7A) $(p<0.05)$. The highest IGF-1 mRNA expression was observed in the $\mathrm{TM}_{2}$ group (15-fold increase) on ED 14 (Figure 7A) $(p<0.05)$. On posthatch days 10 and 28, TM resulted in significant increases of IGF-1 expression compared with the control (Figure 7B) $(p<0.05)$. At 10 days of age, the highest IGF-1 mRNA expression was observed in the $\mathrm{TM}_{2}$ and $\mathrm{TM}_{3}$ groups $(\mathrm{p}<0.05)$, while at 28 days of age, $\mathrm{TM}_{1}$ and $\mathrm{TM}_{2}$ groups presented higher IGF-1 mRNA expression compared with the other treatment groups (Figure 7B) $(p<0.05)$. 
Al-Zghoul MB, Al-Natour MQ, Dalab AS, Alturki OI, Althnaian T, Al-ramadan SY, Hannon KM
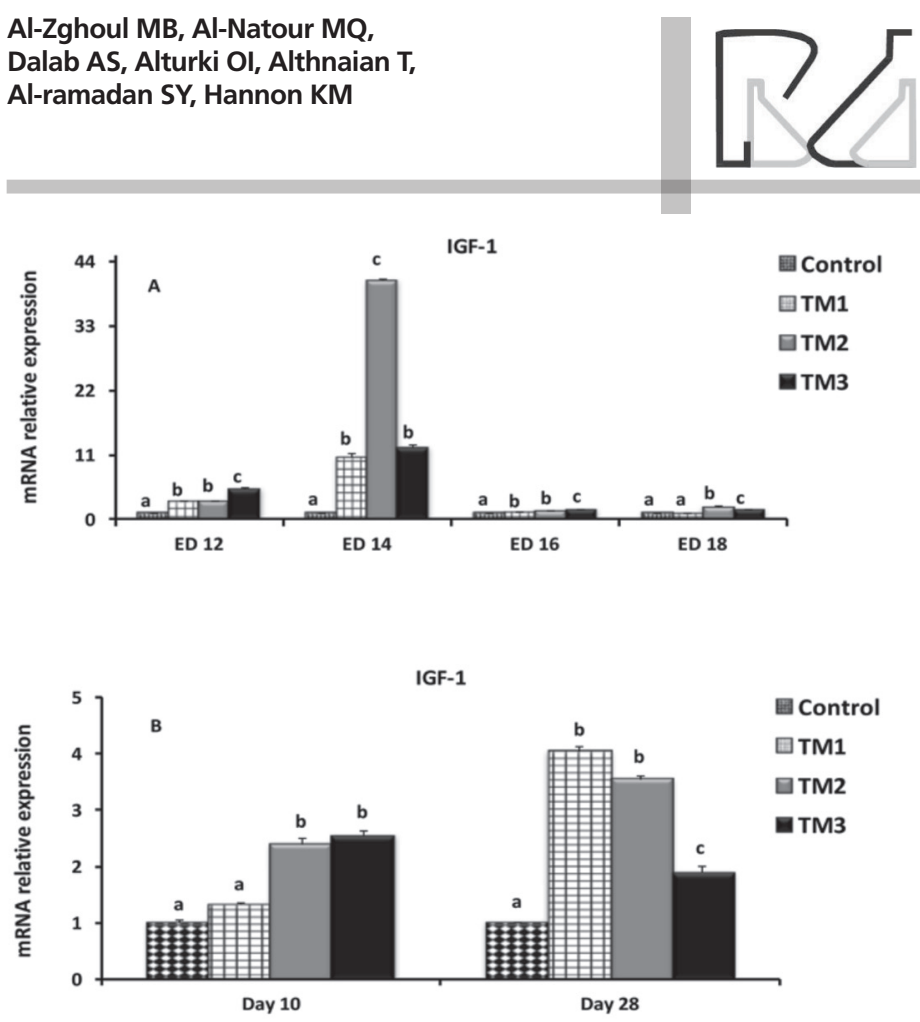

Figure 7 - The effect of thermal manipulation (TM) during embryogenesis on IGF-1 gene expression during embryonic days 12-18 (A) and posthatch days 10 and 28 (B) (n = 20). Control $=37.8^{\circ} \mathrm{C} ; \mathrm{TM} 1=$ Thermal manipulation at $39^{\circ} \mathrm{C}$ for $9 \mathrm{~h} ; \mathrm{TM} 2=$ Thermal manipulation at $39^{\circ} \mathrm{C}$ for $12 \mathrm{~h} ; \mathrm{TM} 3=$ Thermal manipulation at $39^{\circ} \mathrm{C}$ for $18 \mathrm{~h}$. a-d Within the same day, means \pm SD with different superscripts differ significantly $(p<0.05)$.

The effects of embryo thermal manipulation on GH mRNA expression on embryonic days 12, 14, 16, and 18 , and on posthatch days 10 and 28 are shown in figure 8 A-B. On ED 12, GH mRNA expression was significantly higher in the $\mathrm{TM}_{2}$ group $(\mathrm{p}<0.05)$
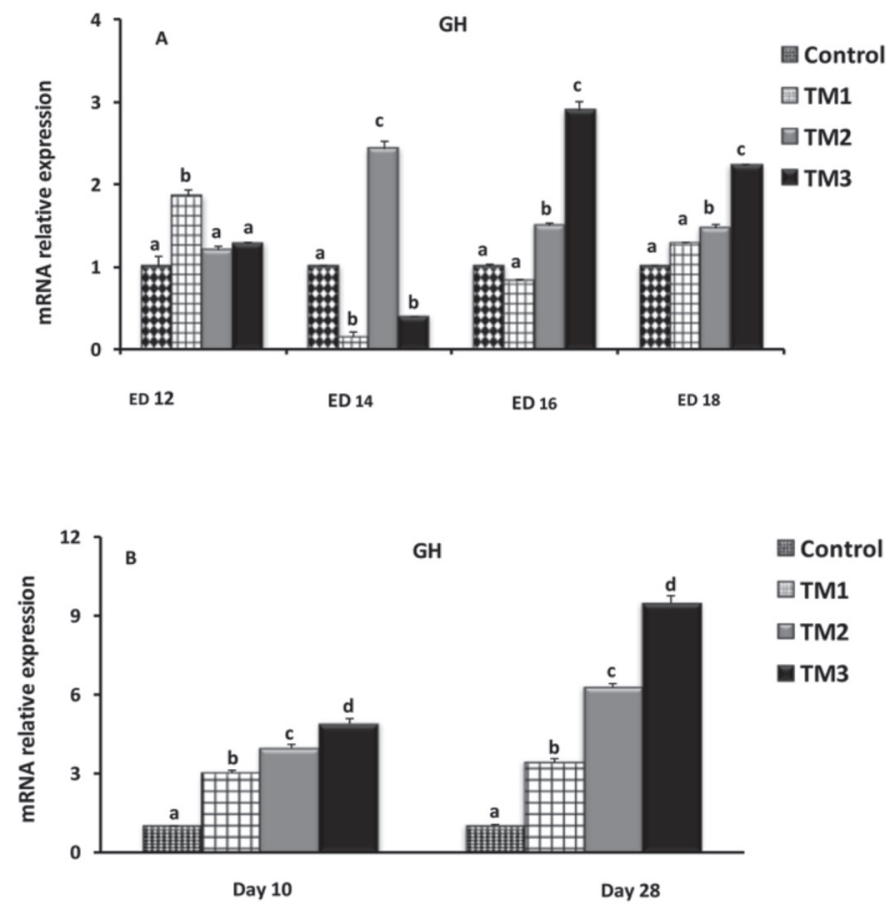

Figure 8 - The effect of thermal manipulation (TM) during embryogenesis on GH gene expression during embryonic days 12-18 (A) and posthatch days 10 and $28(B)(n=20)$. Control $=37.8^{\circ} \mathrm{C} ; \mathrm{TM} 1=$ Thermal manipulation at $39^{\circ} \mathrm{C}$ for $9 \mathrm{~h} ; \mathrm{TM} 2=$ Thermal manipulation at $39^{\circ} \mathrm{C}$ for $12 \mathrm{~h}$; $\mathrm{TM} 3=$ Thermal manipulation at $39^{\circ} \mathrm{C}$ for $18 \mathrm{~h}$. a- $\mathrm{c}$ Within the same day, means \pm SD with different superscripts differ significantly $(p<0.05)$.
Thermal Manipulation Mid-term Broiler Chicken Embryogenesis: Effect on Muscle Growth Factors and Muscle Marker Genes.

compared with other groups, which remained comparable (Figure 8A) ( $p>0.05)$. However, on ED $14, \mathrm{GH}$ mRNA expression was significantly higher in the $\mathrm{TM}_{2}$ group and significantly lower in $\mathrm{TM}_{1}$ and $\mathrm{TM}_{3}$ groups $(\mathrm{p}<0.05)$ compared with the control (Figure 8A). On ED 16 and 18 of age, TM significantly increased mRNA expression of $\mathrm{GH}$ in $\mathrm{TM}_{2}$ and $\mathrm{TM}_{3}$ $(p<0.05)$ compared with the TM, and control groups, which remained comparable (Figure $8 A)(p>0.05)$. On posthatch days 10 and 28, TM significantly increased GH mRNA expression compared to control in a timedependent manner (Figure 8B) $(p<0.05)$.

The effects of embryo thermal manipulation on myostatin mRNA expression on ED 12, 14, 16, and 18 , and on posthatch days 10 and 28 are shown in figure 9 A-B. On ED 12, 14, and 16, TM significantly decreased myostatin mRNA expression relative to the control (Figure 9A) $(p<0.05)$. However, on ED 18, TM significantly increased myostatin mRNA expression compared with the control (Figure $8 A)(p<0.05)$. On posthatch day 10, except for the $\mathrm{TM}_{1}$ group, TM significantly increased myostatin mRNA expression compared with the control (Figure $9 B)(p<0.05)$. On posthatch day $28, \mathrm{TM}$ significantly increased myostatin mRNA expression compared with the control; however, the increase was more pronounced in the TM group followed by the $\mathrm{TM}_{2}$ group, and finally by the $\mathrm{TM}_{3}$ group (Figure 9B) $(p<0.05)$.
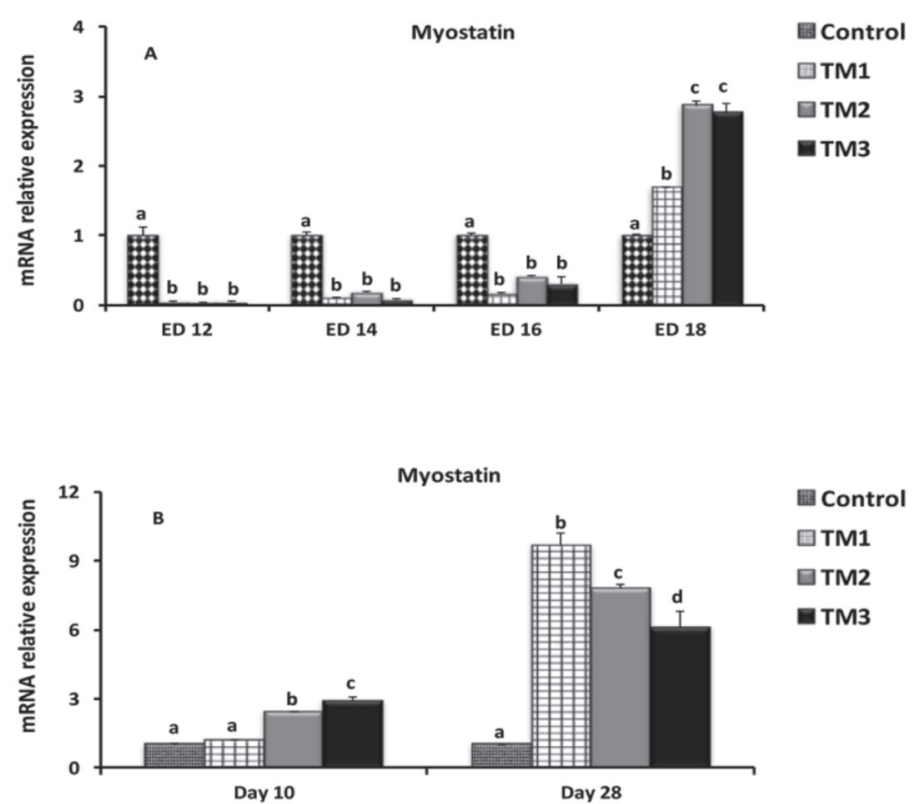

Figure 9 - The effect of thermal manipulation (TM) during embryogenesis on myostatin gene expression during embryonic days 12-18 (A) and posthatch days 10 and $28(B)(n=20)$. Control $=37.8^{\circ} \mathrm{C} ; \mathrm{TM} 1=$ Thermal manipulation at $39^{\circ} \mathrm{C}$ for $9 \mathrm{~h} ; \mathrm{TM} 2=$ Thermal manipulation at $39^{\circ} \mathrm{C}$ for $12 \mathrm{~h}$; TM3 $=$ Thermal manipulation at $39^{\circ} \mathrm{C}$ for $18 \mathrm{~h}$. $a-d$ Within the same day, means $\pm S D$ with different superscripts differ significantly $(p<0.05)$. 
Al-Zghoul MB, Al-Natour MQ,

Dalab AS, Alturki OI, Althnaian T,

Al-ramadan SY, Hannon KM
Thermal Manipulation Mid-term Broiler Chicken Embryogenesis: Effect on Muscle Growth Factors and Muscle Marker Genes.

\section{DISCUSSION}

Due to genetic selection, broiler chicken growth rates have increased, and as a result, the production cycle time has decreased by $60 \%$ over the last 40 years (Hulet, 2007; Baghbanzadeh \& Decuypere, 2008). Thus, the incubation period accounts for a larger proportion of the broiler chicken life span (Havenstein et al., 2003). Studies of incubation conditions (Lourens et al., 2005; Lourens et al., 2007) demonstrate the importance of temperature on embryo and chick development (Decuypere \& Michels, 1992), particularly on hatchability, chick quality, and subsequent live performance (Decuypere \& Michels, 1992; Lourens et al., 2005).

Thermal manipulation at mid-term or at lateterm broiler embryogenesis has been shown to enhance muscle hypertrophy as a result of increasing proliferation and differentiation of both fetal and adult myoblasts, leading to an increased myogenic cell pool in the embryo and posthatch broilers (Piestun et al., 2009; Piestun et al., 2015). The aim of this study was to investigate the molecular basis of muscle growth and development in broiler chickens subjected to daily thermal manipulation $\left(39^{\circ} \mathrm{C}\right.$ and $65 \%$ for 9,12 , or 18 h) during ED 12-18.

In this study, $\mathrm{TM}$ at $39^{\circ} \mathrm{C}$ on ED 12-18 resulted in a slight improvement in embryonic BW of all TM groups on ED 18 when compared with the controls. However, during the first three weeks of age, chicks in all treatment groups had similar body weights ( $p>0.05$ ). However, on posthatch days 28 and 35, the BW of $\mathrm{TM}_{2}$ and $\mathrm{TM}_{3}$ chicks was significantly higher when compared with those of $\mathrm{TM}_{1}$ and controls $(\mathrm{p}<0.05)$.

Halevy et al. (2001) reported that mild heat exposure of broilers at an early age resulted in the acceleration of satellite cell myogenesis mediated by specific local growth factor expression. Furthermore, embryos subjected to $\mathrm{TM}\left(39.5^{\circ} \mathrm{C}\right.$ on ED $16-18$ for 6 h daily), during satellite cell population expansion, resulted in larger myobfiber diameter and increased absolute muscle growth in treated chicks relative to controls until day 35 of age (Piestun et al., 2009). Similarly, $\mathrm{TM}$ during this period at $38.5^{\circ} \mathrm{C}$ for $3 \mathrm{~h}$ resulted in significantly higher absolute pectoral muscle weight in 42-d-old broilers relative to the controls (Hartley et al., 1992; Halevy et al., 2006; Collin et al., 2007). The increase of muscle growth following late-term embryonic TM is thought to have both immediate and long-lasting effects on myogenic cell (satellite cells) proliferation and differentiation, and subsequent hypertrophy (Halevy et al., 2006; Piestun et al., 2009; Piestun et al., 2015).

Myoblast proliferation and differentiation are controlled by the muscle-specific basic helix-loop-helix (bHLH) family of transcription factors (Weintraub, 1993). The MyoD family, containing four basic helix-loop-helix (bHLH) transcription factors (MyoD, myogenic factor-5 (Myf5), myogenin, and myogenic regulatory factor-4 (MRF4)), positively regulates myogenesis (Weintraub, 1993). These factors are expressed in a sequential pattern when satellite cells are activated. Initially, Myf5 and MyoD are expressed in the proliferating progeny, and then myogenin is expressed as the cells begin to differentiate (Beauchamp et al., 2000).

Our data showed that TM resulted in immediate stimulation of muscle MyoD mRNA expression on ED 12 and 14 , with subsequent decline on ED 16 and 18. The highest expression was detected on ED 12 and 14 in embryos exposed to $18 \mathrm{~h}$ of thermal manipulation $(p<0.05)$. On posthatch days 10 and 28 , the only increase in the MyoD expression was observed in the $\mathrm{TM}_{2}$ and $\mathrm{TM}_{3}$ groups $(\mathrm{p}<0.05)$. It seems that TM has an immediate (ED 12 and 14) and late-term (posthatch days 10 and 28) effects on myoblasts proliferation as indicated by the increase of MyoD mRNA expression.

In this study, TM resulted in immediate stimulation of muscle myogenin mRNA expression on ED 12, 14, 16 and 18 in the $\mathrm{TM}_{3}$ group, whereas in the other treatment groups, fluctuating myogenin expression was noted. On posthatch day 10, TM stimulated muscle myogenin mRNA expression compared with the controls $(p<0.05)$, while on posthatch day 28 , higher expression of myogenin was observed only in the $\mathrm{TM}_{3}$ group $(\mathrm{p}<0.05)$. Similarly, it was reported that $\operatorname{TM}\left(39.5^{\circ} \mathrm{C}\right.$ on ED $16-18$ for 3 and 6 h) resulted in the enhancement of cell differentiation, as indicated by myogenin expression levels in the muscle (Piestun et al., 2009). Our results indicate that, out of the TM conditions evaluated $\left(39^{\circ} \mathrm{C}\right.$ for 9,12 or $\left.18 \mathrm{~h}\right), \mathrm{TM}_{3}$ $\left(39^{\circ} \mathrm{C}\right.$ for $\left.18 \mathrm{~h}\right)$ resulted in immediate stimulation (early-term effect) of myogenin mRNA expression during embryogenesis and a delayed stimulation on posthatch days 10 and 28 (late-term effect). These results are in contrast with those of Piestun et al. (2009) who reported that similar increase of muscle hypertrophy in heat-treated embryos, regardless TM length (3h vs. 6h).

In this study, $\mathrm{TM}\left(39^{\circ} \mathrm{C}\right.$ for $\left.18 \mathrm{~h}\right)$ significantly increased muscle PCNA mRNA expression on ED 14, 16 and $18(p<0.05)$, whereas TM $\left(39^{\circ} \mathrm{C}\right.$ for $\left.12 \mathrm{~h}\right)$ significantly increased muscle PCNA mRNA expression 
on ED 18 ( $\mathrm{p}<0.05)$. On posthatch days 10 and 28, TM significantly increased PCNA expression $(p<0.05)$. Interestingly, the magnitude of the expression was time - and duration - dependent. The highest expression was detected on ED 14 and 16 in embryos exposed to $18 \mathrm{~h}$ of thermal manipulation $\left(\mathrm{TM}_{3}\right) \quad(\mathrm{p}<0.05)$. Furthermore, on posthatch days 10 and 28, the highest PCNA expression was observed in embryos exposed to $18 \mathrm{~h}$ of thermal manipulation $\left(\mathrm{TM}_{3}\right)(\mathrm{p}<0.05)$.

The paired-box transcription factor Pax7 is selectively expressed in quiescent and proliferating satellite cells and is thought to play a role in their self-renewal (Oustanina et al., 2004; Zammit et al., 2004). Pax7 has been suggested as an early marker of myogenesis during posthatch muscle growth, and its expression is sustained by satellite cells in the adult chicken muscle (Halevy et al., 2004; Allouh et al., 2008). Pax7 plays a key role in the formation of adult mouse skeletal muscle (Seale et al., 2000). Furthermore, Pax7 is expressed during myoblast proliferation and declines during differentiation (Halevy et al., 2004).

Our data showed that TM resulted in immediate stimulation of muscle Pax7 mRNA expression on ED 12 and $14(p<0.05)$. On ED 16, an increase in the Pax7 expression was only detected in $\mathrm{TM}_{3}$, whereas on ED 18, higher expression of Pax7 was detected in the $\mathrm{TM}_{2}$ and $\mathrm{TM}_{3}$ groups $(\mathrm{p}<0.05)$. Furthermore, Pax7 expression was significantly increased on posthatch day 10 and remained high on posthatch day $28(p<0.05)$. Interestingly, the magnitude of the expression was time - and duration - dependent.

TM had early-term (ED 12-18) and late-term (posthatch days 10 and 28) effects in elevating myoblast proliferation relative to controls. This was shown by the higher PCNA and Pax7 mRNA expressions in the pectoral muscle of TM chicks compared with the controls. Previously, Piestun et al. (2016) reported that $\mathrm{TM}\left(39.5^{\circ} \mathrm{C}\right.$ on ED 16-18) resulted in immediate (ED17) and later effect (up to 2 wks posthatch) on myoblast proliferation, as shown by higher DNA incorporation of thymidine, higher number of muscle cells expressing PCNA in intact muscle, and higher Pax7 protein levels. Those authors suggested that TM enhanced muscle hypertrophy by stimulating myogenic progeny cells (satellite cells) proliferation.

In mammals and birds, muscle cell proliferation and differentiation are controlled by growth factors and hormones that play a pivotal role in promoting the growth of skeletal muscle. The proliferation of satellite cells is regulated by several growth factors and hormones including: insulin growth factor-1 (IGf-1)
(Adams \& McCue, 1998; Adams et al., 1999), fibroblast growth factor (Florini et al., 1996), growth hormone (Sadowski et al., 2001) and hepatocyte growth factor (Gal-Levi et al., 1998).

Insulin-like growth factors (IGF-1 and IGF-2) comprise a family of polypeptide hormones related in its structure to insulin, and have multifunctional metabolic and anabolic properties. IGF-1 is produced and secreted in the liver, and hasan endocrine function in many tissues, but it is also produced in many other cell types to provide paracrine and autocrine functions, such as in muscle tissues (Bhaumick \& Bala, 1991; Baker et al., 1993, Russell et al., 1998). IGF-I is the main local growth factor, playing a role in both muscle growth and hypertrophy via its effect on satellite cells (Adams \& McCue, 1998; Adams et al., 1999).

In broilers, the crucial proliferation and differentiation of satellite cells occurs during the first days posthatch, after which satellite cell population declines dramatically (Halevy et al., 2001). Previously, it was shown that TM resulted in a rapid induction of IGF1 gene expression in the breast muscle derived from thermally-manipulated broiler embryos, concomitantly with the rise in satellite cell proliferation. IGF-1 has been also shown to stimulate primary satellite cell proliferation in rats (Allen \& Boxhorn, 1989) and in chickens (Duclos et al., 1991). In the present study, TM resulted in immediate stimulation of muscle IGF1 mRNA expression during embryogenesis and on posthatch days 10 and $28(p<0.05)$. Interestingly, the magnitude of the expression was time - and duration - dependent. The highest expression was detected on ED 14 in embryos exposed to $12 \mathrm{~h}$ of thermal manipulation $(p<0.05)$. Furthermore, IGF-1 increased significantly on posthatch day 10 and remained high on posthatch day 28 ( $p<0.05)$. Previously, high IGF-1 gene expression was observed in chicken breast muscle tissues in response to early age thermal manipulation (24 h at 3 daysof age) (Halevy et al., 2001), TM at 38.5 ${ }^{\circ} \mathrm{C}$ on ED 16-18 (Halevy et al., 2006), and TM at 39.5 ${ }^{\circ} \mathrm{C}$ on ED 16-18 (Piestun et al., 2009). This increase of IGf-1 expression was associated with significant increases in the BW of thermally-manipulated chicks on posthatch days 28 and 35 ( $p<0.05)$.

Our data also indicate that TM resulted in immediate stimulation of muscle GH mRNA expression during embryogenesis and on posthatch days 10 and 28 . Interestingly, the magnitude of the expression was time - and duration - dependent. The highest expression was detected on ED 16 and 18 in embryos exposed to $18 \mathrm{~h}$ of thermal manipulation $\left(\mathrm{TM}_{3}\right) \quad(\mathrm{p}<0.05)$. 
Al-Zghoul MB, Al-Natour MQ, Dalab AS, Alturki OI, Althnaian T, Al-ramadan SY, Hannon KM
Thermal Manipulation Mid-term Broiler Chicken Embryogenesis: Effect on Muscle Growth Factors and Muscle Marker Genes.
Furthermore, GH significantly increased on posthatch day 10 and remained high on posthatch day 28, with highest expression was again observed in $\mathrm{TM}_{3}$ group $(p<0.05)$.

The growth hormone plays a pivotal role in promoting the growth of mammalian skeletal muscle. It has been shown that administration of $\mathrm{GH}$ to humans, ruminants, and pigs enhanced their skeletal muscle growth (Chung et al., 1985; Campbell et al., 1989; Grant et al., 1991; Brameld et al., 1996; Tavares et al., 2013; Jiang \& Ge, 2014). Furthermore, IGF-I has been suggested to mediate the effect of $\mathrm{GH}$ on muscle growth. Isgaard et al. (1989) showed that, following hypophysectomy, IGF-I mRNA expression decreased and the replacement therapy with human $\mathrm{GH}$ restored those levels in the heart and skeletal muscles. IGF-I mRNA levels are also stimulated inliver tissue and skeletal muscle as a result of $\mathrm{GH}$ administration (Grant et al., 1991).

Finally, TM resulted in an immediate decline of muscle myostatin mRNA expression on embryonic days 12, 14 and 16. However, starting from ED 18 and on posthatch days 10 and 28, TM significantly increased muscle myostatin mRNA expression $(p<0.05)$.

Myostatin, known as growth/differentiation factor-8, is a member of the transforming growth factor- $\beta$ (TGF- $\beta$ ) family of secreted regulatory factors (McPherronm and Lee, 1997). Growth factors, such as myostatin, have also been identified as key peptides in the regulation of vertebrate's myogenesis (McPherronm \& Lee, 1997; Bass et al., 1999). Myostatin peptide acts as a negative regulator of muscle growth (McPherronm \& Lee, 1997; Bass et al., 1999). A myostatin mutation has been found in "double-muscled" cattle, which have, on average, $20 \%$ more muscle mass than normal cattle (Bass et al., 1999). In-vitro studies demonstrate that recombinant myostatin inhibits the proliferation of $\mathrm{C} 2 \mathrm{C} 12$ myoblasts and bovine myoblasts derived from 160-day-old fetuses (Thomas et al., 2000). Also, the inhibitory effect of myostatin was shown to be reversible, as myoblasts maintained their ability to proliferate when myostatin was removed (Kocamis \& Killefer, 2002). Furthermore, satellite cell proliferation and differentiation are inhibited by myostatin, which maintains them in their quiescent state and down regulates the expression of MyoD family members (Halevy et al., 2006).

Together, these findings suggest a differential effect of various periods of TM on broiler muscle growth and development. It seems that embryo thermal manipulation at $39{ }^{\circ} \mathrm{C}$ for $18 \mathrm{~h}$ on ED $12-18$ was optimal for the enhancement of muscle growth and development. This was evidenced by the significant increases in the embryonic BW and the posthatch BW at days 28 and 35 of age $(p<0.05)$. The improvement of the body weight was associated with immediate and long-lasting effects of TM on the expression of muscle growth factors (IGF-1 and $\mathrm{GH}$ ) and muscle marker genes (MyoD, myogenin, and Pax7).

\section{CONCLUSIONS}

The results of the present study demonstrated that TM, by altering incubation temperature and relative humidity to $39^{\circ} \mathrm{C}$ and $65 \% \mathrm{RH}$ daily during embryonic days 12-18 leads to changes in the mRNA expression of muscle marker genes (MyoD, myogenin and Pax7) and muscle growth factors (IGF-1 and GH), which were associated with body weight improvement during embryogenesis and posthatch. It seems that the out of the three different TM durations (9, 12 or $18 \mathrm{~h}$ ), 18 hours at $39^{\circ} \mathrm{C}$ promoted the best performance parameter (body weight).

\section{ACKNOWLEDGMENTS}

The authors would like to thank the Jordan University of Science and Technology, the Deanship of Research for their partial support, grant number (180/2007). This project was funded by National Plan for Science, Technology and Innovation (MAARIFAH)King Abdulaziz City for Science and Technology-The king of Saudi Arabia, grant number (11-B10 180506).

\section{REFERENCES}

Adams GR, Haddad F, Baldwin KM. Time course of changes in markers of myogenesis in overloaded rat skeletal muscles. Journal of Applied Physiology 1999;87(5):1705-1712.

Adams GR, McCue SA. Localized infusion of IGF-I results in skeletal muscle hypertrophyin rats. Journal of Applied Physiology 1998;84(5):17161722.

Al-Zghoul MB, Ismail ZB, Dalab AE, Al-Ramadan A, Althnaian TA, AlRamadan SY, et al. Hsp90, Hsp60 and HSF-1 genes expression in muscle, heart and brain of thermally manipulated broiler chicken. Research in Veterinary Science 2015;99:105-111.

Al-Zhgoul MB, Dalab AE, Ababneh MM, Jawasreh KI, Al Busadah KA,Ismail ZB. Thermal manipulation during chicken embryogenesis results inenhanced $\mathrm{Hsp70}$ gene expression and the acquisition of thermotolerance. Research in Veterinary Science 2013;95(2):502-507.

Allen RE, Boxhorn LK. Regulation of skeletal muscle satellite cell proliferation and differentiation by transforming growth factor-beta, insulin-like growth factor I, and fibroblast growth factor. Journal of Cellular Physiology 1989;138(2):311-315. 
Al-Zghoul MB, Al-Natour MQ,

Dalab AS, Alturki OI, Althnaian T,

Al-ramadan SY, Hannon KM

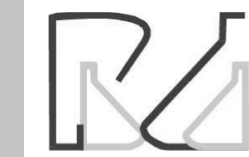

Thermal Manipulation Mid-term Broiler Chicken Embryogenesis: Effect on Muscle Growth Factors and Muscle Marker Genes.
Allouh MZ, Yablonka-Reuveni Z, Rosser BW. Pax7 reveals a greater frequency and concentration of satellite cells at the ends of growing skeletal muscle fibers. Journal of Histochemistry \& Cytochemistry 2008;56(1):77-87.

Baghbanzadeh A, Decuypere E. Ascites syndrome in broilers: physiological and nutritional perspectives. Avian Pathology 2008;37(2):117-126.

Baker J, Liu JP, RobertsonEJ, Efstratiadis A. Role of insulin-like growth factors in embryonic and postnatal growth. Cell 1993;75(1):73-82.

Bass J, Oldham J, Sharma M, Kambadur R. Growth factors controlling muscle development. Domestic Animal Endocrinology 1999;17(2):191197.

Beauchamp JR, Heslop L, Yu D, Tajbakhsh S, Kelly R, Wernig A, et al. Expression of CD34 and Myf5 defines the majority of quiescent adult skeletal muscle satellite cells. Journal of Cell Biology 2000;151:12211233.

Bhaumick B, Bala RM. Differential effects of insulin-like growth factors I and II on growth, differentiation and glucoregulation in differentiating chondrocyte cells in culture. Acta Endocrinologica 1991;125(2):201211.

Brameld JM, Atkinson JL, Saunders JC, Pell JM, Buttery PJ, Gilmour RS. Effects of growth hormone administration and dietary protein intake on insulin-like growth factor I and growth hormone receptor mRNA Expression in porcine liver, skeletal muscle, and adipose tissue. Journal of Animal Science 1996;74(8):1832-1841.

Campbell RG, Steele NC, Caperna TJ, McMurtry JP, Solomon MB, Mitchell $\mathrm{AD}$. Interrelationships between sex and exogenous growth hormone administration on performance, body composition and protein and fat accretion of growing pigs. Journal of Animal Science 1989;67(1):177186.

Chung CS, Etherton TD, Wiggins JP. Stimulation of swine growth by porcine growth hormone. Journal of Animal Science1 985;60(1):118-130

Cobb-Vantress. Broiler management guide Cobb 500. Guapiaçu: Siloam Springs; 2013.

Collin A, Berri C, Tesseraud S, Rodon F, Skiba E, Cassy S, et al. Effects of thermal manipulation during early and late embryogenesis on thermotolerance and breast muscle characteristics in broiler chickens. Poultry science2007;86(5):795-800.

Cornelison DD, Wold BJ. Single-cell analysis of regulatory gene expression in quiescent and activated mouse skeletal muscle satellite cells. Developmental Biology 1997;191(2):270-283.

Decuypere $\mathrm{E}$, Michels $\mathrm{H}$. Incubation-temperature as a management tool-A review. World's Poultry Science Journal 1992;48:28-38.

Duclos MJ, Wilkie RS, Goddard C. Stimulation of DNA synthesis in chicken muscle satellite cells by insulin and insulin-like growth factors: evidence for exclusive mediation by a type-I insulin-like growth factor receptor. Journal of Endocrinology 1991;128(1):35-42.

Florini JR, Ewton DZ, Coolican SA. Growth hormone and the insulin-like growth factor system in myogenesis [review]. Endocrine Reviews 1996;17(5):481-517

Gal-Levi R, Leshem Y, Aoki S, Nakamura T, Halevy O. Hepatocyte growth factor plays a dual role in regulating skeletal muscle satellite cell proliferation and differentiation. Biochimica et Biophysica Acta 1998; 1402(1):39-51

Grant AL, Helferich WG, Kramer SA, Merkel RA, Bergen WG. Administration of growth hormone to pigs alters the relative amount of insulin- like growth factor-I mRNA in liver and skeletal muscle. Journal of Endocrinology 1991;130(3):331-338

Halevy O, Krispin A, Leshem Y, McMurtry JP,Yahav S. Early-age heat exposure affects skeletal muscle satellite cell proliferation and differentiation in chicks. American Journal of Physiology-Regulatory, Integrative and Comparative Physiology 2001;281(1):R302-R309

Halevy O, Piestun Y, Allouh MZ, Rosser BW, Rinkevich Y, Reshef Ret al. Pattern of Pax7 expression during myogenesis in the posthatch chicken establishes a model for satellite cell differentiation and renewal. Developmental Dynamics 2004;231(3):489-502.

Halevy O, Yahav S, Rozenboim I. Enhancement of meat production by environmental manipulation in embryo and young broilers. World's Poultry Science Journal 2006;62(03):485-497.

Hartley RS, Bandman E, Yablonka-Reuveni Z. Skeletal muscle satellite cells appear during late chicken embryogenesis. Developmental Biology $1992 ; 153(2): 206-216$

Havenstein GB, Ferket PR, Qureshi MA. Carcass composition and yield of 1957 versus 2001 broilers when fed representative 1957 and 2001 broiler diets. Poultry Science 2003;82(10):1509-1518.

Hawke TJ, Garry DJ. Myogenic satellite cells: physiology to molecular biology. Journal of Applied Physiology 2001;91(2):534-551.

Hulet RM. Managing incubation: where are we and why? Poultry Science 2007:86(5):1017-1019.

Isgaard J, Nilsson A, Vikman K, Isaksson OG. Growth hormone regulates the level of insulin-like growth factor-I mRNA in rat skeletal muscle. Journal of Endocrinology 1989;120(1):107-112.

Jiang $\mathrm{H}$, Ge $\mathrm{X}$. Meat science and muscle biology symposium- mechanism of growth hormone stimulation of skeletal muscle growth in cattle. Journal of Animal Science 2014;92(1):21-29.

Kocamis $\mathrm{H}$, Killefer J. myostatin expression and possible functions in animal muscle growth. Domestic Animal Endocrinology 2002;23(4):447-454.

Koohmaraie M, Kent MP, Shackelford SD, Veiseth E, Wheeler TL. Meat tenderness and muscle growth: is there any relationship? Meat Science 2002;62(3):345-352.

Lourens A, van den Brand H, Heetkamp MJ, Meijerhof R, Kemp B. Effects of eggshell temperature and oxygen concentration on embryo growth and metabolism during incubation. Poultry Science 2007;86(10):21942199

Lourens A, Van den Brand $H$, Meijerhof $R$, Kemp B. Effect of eggshell temperature during incubation on embryo development, hatchability, and posthatch development. Poultry Science 2005;84(6):914-920.

McPherronm AC, Lee SJ. Double muscling in cattle due to the myostatin gene. Proceedings of the National Academy of Sciences 1997;94:12457-12461.

Ordahl CP, Williams BA, Denetclaw W. Determination and morphogenesis in myogenic progenitor cells: an experimental embryological approach. Current Topics in Developmental Biology 2000;48:319-367.

Oustanina S, Hause G, Braun T. Pax7 directs postnatal renewal and propagation of myogenic satellite cells but not their specification. The EMBO Journal 2004;23(16):3430-3439.

Piestun Y, Harel M, Barak M, Yahav S, Halevy O. Thermal manipulations in late-term chick embryos have immediate and longer term effects on myoblast proliferation and skeletal muscle hypertrophy. Journal of Applied Physiology 2009;106(1):233-240. 
Al-Zghoul MB, Al-Natour MQ,

Dalab AS, Alturki OI, Althnaian T,

Al-ramadan SY, Hannon KM Embryogenesis: Effect on Muscle Growth Factors and Muscle Marker Genes.
Piestun Y, Ruzal M, Shinder D, Halevy O, Yahav S. The effect of thermal manipulations during the development of the thyroid and adrenal axes on in-hatch and post-hatch thermoregulation. Journal of Thermal Biology 2008a;33(7):413-418.

Piestun Y, Shinder D, Ruzal M, Halevy O, Brake J, Yahav S. Thermal manipulations during broiler embryogenesis: effect on the acquisition of thermotolerance. Poultry Science 2008b;87(8):1516-1525.

Piestun $Y$, Yahav S, Halevy O. Thermal manipulation during embryogenesis affects myoblast proliferation and skeletal muscle growth in meat-type chickens. Poultry Science 2015;94(10):2528-2536.

Russell JW, Windebank AJ, Schenone A, Feldman EL. Insulin-like growth factor-I prevents apoptosis in neurons after nerve growth factor withdrawal. Journal of Neurobiology 1998;36(4):455-467.

Sadowski CL, Wheeler TT, Wang LH, Sadowski HB. GH regulation of IGF-I and suppressor of cytokine signaling gene expression in C2C12 skeletal muscle cells. Endocrinology 2001;142(9):3890-3900.

Seale P, Sabourin LA, Givgis -Gabardo A, Mansuori A, Gruss P, Rudnicki MA. Pax7 is required for the specification of myogenic satellite cells. Cell 2000;102:777-786.
Tavares AB, Micmacher E, Biesek S, Assumpcao R, Redorat R, Veloso U, et al. Effects of Growth Hormone Administration on Muscle Strength in Men over 50 Years Old. International Journal of Endocrinology 2013;2013:942030

Thomas M, Langley B, Berry C, Sharma M, Kirk S, Bass J, Kambadur R. Myostatin, a negative regulator of muscle growth, functions by inhibiting myoblast proliferation. The Journal of Biological Chemistry 2000;275(51):40235-40243.

Weintraub $H$. The MyoD family and myogenesis: redundancy, networks, and thresholds. Cell 1993;75(7):1241-1244.

Yahav S, Rath R, Sasson A, Shinder D. The effect of thermal manipulations during embryogenesis of broiler chicks (Gallus domesticus) on hatchability, body weight and thermoregulation after hatch. Journal of Thermal Biology 2004;29(4-5):245-250.

Yalcin S, Siegel P. Exposure to cold or heat during incubation on developmental stability of broiler embryos. Poultry Science 2003;82(9):1388-1392.

Zammit PS, Golding JP, Nagata $Y$, Hudon V, Partridge TA, Beauchamp JR. Muscle satellite cells adopt divergent fates a mechanism for selfrenewal? The Journal of Cell Biology 2004;166(3):347-357. 
In the article Thermal Manipulation Mid-term Broiler Chicken Embryogenesis: Effect on Muscle Growth Factors and Muscle Marker Genes published in the Revista Brasileira de Ciência Avícolas/Brazilian Journal of Poultry Science, v18 (4):607-618, in page 607 where it was written

\title{
-Author(s)
}

\author{
Al-Zghoul MB' \\ Al-Natour MQ" \\ Dalab AS"II \\ Alturki Ol"II \\ Althnaian T'II \\ Al-ramadan SYIII \\ Hannon KM"
}

' Department of Basic Medical Veterinary Sciences, Faculty of Veterinary Medicine, Jordan University of Science and Technology.

" Department of Veterinary Pathology and Public Health, Faculty of Veterinary Medicine, Jordan University of Science and Technology.

III Department of Anatomy, College of Veterinary Medicine, King Faisal University, Saudi Arabia.

Iv Department of Basic Medical Sciences, Purdue University, West Lafayette, IN, United States.

\section{the correct form is}

\section{author(s)}
Al-Zghoul MB'
Al-Natour MQ"
Dalab AS"II
Alturki Ol"I
Althnaian T'II
Al-ramadan SYII
Hannon KM
El-Bahr SMv

I Department of Basic Medical Veterinary Sciences, Faculty of Veterinary Medicine, Jordan University of Science and Technology.

" Department of Veterinary Pathology and Public Health, Faculty of Veterinary Medicine, Jordan University of Science and Technology.

III Department of Anatomy, College of Veterinary Medicine, King Faisal University, Saudi Arabia.

Iv Department of Basic Medical Sciences, Purdue University, West Lafayette, IN, United States.

$\checkmark$ Department of Biochemistry, Faculty of Veterinary Medicine, Alexandria University, Egypt Department of Physiology, Biochemistry and Pharmacology, College of Veterinary Medicine, King Faisal University, Saudi Arabia. 